\title{
Women's influence on Chrétien de Troyes
}

\author{
Madeline Dorothy Barney ${ }^{\mathrm{a}}$
}

After researching tourbadours, historical women, and the French courts of love, I came to the conclusion that Guinevere is a fictional character in Chrétien de Troyes Lancelot or The Knight of the Cart.

Keywowrds: chrétien de troyes; lancelot; guinevere; marie de champagne; court of love; troubadours

Chrétien de Troyes changed and developed the Arthurian legend of the English history with a French twist. He was of French origin but not much is known of his life, other than he lived during the third quarter of the twelfth century ${ }^{1}$. As his name origin explains, he had ties to antiquity as well as the Champagne region of France. He wrote five surviving romances which all include several themes and motifs common to the stories of antiquity. All of his romances include narratives of adventure, the glory of combat, and love $^{2}$. Chrétien is considered the greatest of the French medieval poets. He can also be considered a male troubadour, a poet, a storyteller, and a master of rhetoric ${ }^{3}$. His most known work, Lancelot or The Knight of the Cart, integrates the ideals of chivalry, knighthood, and courtly love into French culture during the time period he was writing ${ }^{4}$. His patrons, Marie de Champagne and later, Philippe d'Alsace, count of Flounders, received the best literature to represent their ideals for France 5 . Upon researching Lancelot or The Knight of the Cart, women, troubadours, and courtly love during the $12^{\text {th }}$ century, I came to the conclusion that Chrétien de Troyes' Guinevere was not based on historical figures but rather, the story provided commentary of culture and expectations. He presented images of women that were deemed as ideal, and sometimes even perfection, but not realistic; her actions and relationship with Lancelot was not appropriate for a Queen but her love was natural and unconditional.

To begin, one must understand troubadours to understand the situation of language and entertainment during the time Chrétien was writing and developing his romances, specifically Lancelot or The Knight of the Cart. Chrétien was considered a troubadour in the court of Marie de Champagne and later in the court of Philippe d'Alsace, count of Flounders. The Oxford English Dictionary defines a troubadour as, "one of a class of lyric poets, living in Southern France ... from the eleventh to the thirteenth centuries, who sang in Provençal, chiefly of chivalry and gallantry." An additional definition is, "a composer or writer in support of some cause of interest." Chrétien states in the beginning of his Lancelot or The Knight of the Cart text that his specific agenda is to please Marie de Champagne with the romance of King Arthur. The majority of troubadours were male but there were some female; the female troubadours had a different agenda than the males. The region of Occitania in Southern France is notable for the amount of female troubadours that are documented. Most of the female troubadours are left without names to the few texts that remain. These female writers and entertainers are known to be exclusively of noble and aristocratic families but not much else in known of their lives ${ }^{6}$. Overall, the female voice is not entirely removed or muted from history in the art of the troubadours' lyric poetry, but it is vastly overshadowed by the everlasting and overbearing voice of the men in patriarchal society of Southern France.

The agenda presented in the male troubadours' stories and poems, remains consistent among most troubadours in France during the twelfth century. The stories consist of courtly love and idealized expectations of lovers' behaviors in society, with quests of adventure and chivalry. Courtly love, is "of persons (or their manners): having the manners or breeding befitting the court; polish, refined, of a high-bred courtesy" as defined by the Oxford English Dictionary. Jean Markale explains in her book, Courtly Love: The Path of Sexual Initiation, that courtly love, "became the rage throughout European aristocratic society thanks primarily to the songs of the troubadours and the "courtly" romances, its birth remains thoroughly obscure-like the causes that prompted it, for that matter ${ }^{7}$." The definition of courtly love may be slightly different, but the general meaning and intention remains the same. The troubadours developed a new type of love and fixation with desire for the perfect women. This new and improved love was specifically for nobility and the aristocratic class. The courtly love also presented the image of the ideal man, in the form of a chivalric knight. As the author of The World of the Troubadours: Medieval Occitan Society, c. $1100-$ c. 1300 , Linda M. Paterson explains the changing roles of courtly love in the images presented in the male troubadour stories. She says, "Presented in the form of advice offered by the author to a young man suffering from love, it instructs how to please ladies by wearing elegant and fashionable clothes, keeping oneself graciously and according to correct etiquette, and choosing well- mannered servants ${ }^{8}$." These images help enforce societal expectations on how one should act. The value of love has begun to be appreciated beginning in the medieval period. Marriage, ideally, can now be for love rather than for social, political, and/or wealth gain; or an aristocratic man can find himself an acceptable lover to admire publically. The value of love has risen among the aristocrats in the various regions of France presented as a form of entertainment as the stories and poems by the male troubadours.

Following, the male troubadours also wrote of the knighthood as ideal in their poems and stories. The value of good knights and chivalric deeds was important during the twelfth century because it was a time of universal unrest and violence. The Crusades were a reality for most men of the 
period. The aristocratic men were anticipated to be good fighters and warriors leading the men into war. Paterson explains, "The lyric shows some blending of courtly ideals with the concept of knighthood, but there is no clear turning point . . . the chivalric ideals seems weak, and the lyric even betrays conscious resistance to them ${ }^{9}$." The inclusion of chivalric deeds and knighthood could be to prepare the young men how to be good men and idealized knights in battle or leading a life as a civilian. The troubadours presented images of the ideal and brave men. They also presented images of the severely flawed man. For example, not all stories by troubadours idealized knights. Some of the poets, like Chrétien de Troyes, poked fun at the idealized man and his actions regarding courtly love. King Arthur was not a fitting king in Lancelot or the Knight of the Cart. Also, Lancelot was completely in love with Guinevere and blindly walked into bad situations because he was so in love with her. He did not think of his duties as a knight because his love was allencompassing. William W. Kibler translated Chrétien de Troyes' Lancelot or The Knight of the Cart into modern English from middle French. Kibler's translation portrays Lancelot as a careless and irresponsible knight, saying

He would regret this moment of hesitation and be accursed and shamed for it; he would come to consider himself ill-used. But Reason, who does not follow Love's command, told him to beware of getting in, warned and counseled him not to do anything for which he might incur disgrace or reproach. Reason, who dared tell him this, spoke from the lips, not from the heart; but Love, who held sway within his heart, urged and commanded him to climb into the cart at once, Because Love ordered and wished it, he jumped in; since Love ruled his action, the disgrace did not matter ${ }^{10}$.

He fulfills the ideals of courtly love being all encompassing. However, he does not act as a good knight should because he prioritizes a woman over all else. He places the value of love before the value of reason. He does not act as the ideal and well-educated man should because he does not think using reason before he makes a substantial decision. Lancelot, in general, does not think at all because he is preoccupied with thoughts of Guinevere. Lancelot is not the ideal knight but rather, he is the ideal lover and greatest example of courtly love in the French medieval romance.

The female troubadours' stories and lyric poems present a vastly different image of love. The female voice in is quiet but present, with very few representatives. In one perspective, the voice of the female troubadours could be the voice of reason and honesty during the medieval period in France. Meg Bogin, in her book The Women Troubadours: An Introduction to the Women Poets if the Twelfth Century Provence and a Collection of Their Poems, explains the different agendas and representations of love and gender differences. Bogin explains, "The women, unlike the men, do not idealize the relationships they write about, nor do they use the lover and the lady as allegorical figures . . . they do not worship men, nor do they seem to want to be adored themselves ${ }^{11}$." In Chrétien's Lancelot, Lancelot idealizes Guinevere throughout the story. Although, Guinevere does not demand the courts attention and praise, Lancelot praises the Queen. He describes her as the most beautiful woman; she is almost a divine image to Lancelot. Guinevere is the perfect example of how the image of women is illuminated through the male troubadours' romantic perspective. Chrétien helps romanticize, sentimentalize, and idealize the image of women in his lyric poems. As for Paterson, she explains an alternative perspective to the understanding of the valued female troubadours. She says, "Some scholars have identified elements of a female rhetoric in trobairitz poetry, relating to particularly intense feelings of frustration and deprivation, and a particular concern with real relationships with members of the other $\operatorname{sex}^{12}$." Paterson explains that the female troubadours challenge some of the conventions of courtly love in their artistic expressions of poetry and story telling. Although, there are very few recovered documents of the female troubadour, their influence is appreciated and valued. The female's perspective on courtly love is considered biased but also reliable. However, the male perspective is also biased but not realistic or reliable. The male perspective of a relationship with a woman is sublime; the relationship is the most ideal of all relationships. The female's perspective is may have a negative tone but it is more practical, rational and honest.

Troubadours wrote of serious social issues but added satirical commentary to make the lyric poems and stories more lighthearted and comic. Most of their work appealed to both the aristocracy and the lower class. Frances and Joseph Giles explain in their book, Women in the Middle Ages: The Lives of Real Women in a Vibrant Age of Transition, the appeal of troubadour entertainment in the different levels of the social hierarchy. The Giles' explain, "Medieval literature was neither the first nor the last to treat adultery as romantic for the upper classes and comic for the lower ${ }^{13}$." Much of the romantic literature left behind from the troubadours and other writers, appealed to more than one class. The issue of adultery was comic but serious, nonetheless, for all levels of the social hierarchy in France. The troubadours' texts tended to have sympathy for love and rationalizing the sins associated with the love, like lust and the act of sex. The twelfth century troubadour, Andres Capellanus explained in the treatise De Amore, "love could not exist "between two people who are married to each other" but could only last "outside the bonds of wedlock ${ }^{14}$." The amount of literature and manuscripts in readable condition illuminate that adultery was a common topic written about during the medieval period. Although, the few Christian people during the twelfth century thought of marriage as a sacrament, many people did not actually remain monogamous and without sin. The Giles explain the double standard of adultery during the medieval period. They illuminate the world of infidelity providing facts of the sinners past, specifically about the men of nobility, "openly kept mistresses and spawned illegitimate children, while erring wives were disgraced and repudiated, their lovers castrated or killed. In a wife's adultery the affront was perceived not to mortality but to the husband's honor ${ }^{15}$." The honor of a man's surname was much more valuable than the value of a wife. A treasonous wife could be replaced by someone better and younger. However, the low blows to a man's name and reputation could not be easily recovered. Also, the adulterous man did not face the same consequences as an adulterous woman. Since a man could not bear illegitimate children, his reputation and surname was not threatened by the lustful acts. The women in adulterous relationships were forced to bear the burden of pregnancy. The adulterous behavior, for the aristocratic social class, was 
a game for the men with the women to be punished, replaced, and disciplined.

Despite the fact that adultery was a severe act against a man's family, history holds several public accounts of faithlessness in marriages. The Oxford Dictionary of National Biography explains that Eleanor of Aquitaine was a bold woman who was not controlled by a man. She was married several times and supposedly had affairs with men of nobility. She was unhappy on some marriages but fought for her beliefs. She went on crusades with her first husband and sought out pilgrimages. Also, she was the mother of Marie de Champagne; she had several marriages in her marriages, many of her children became members of the high nobility. Her daughter Marie commissioned Chrétien's writing of Lancelot or The Knight of the Cart. Chrétien and other authors of the period would know the history of these women, their importance, and their influence on society and politics. However, this does not mean that the adulterous relationships within the troubadour stories are based on the lives of these women of the aristocratic class. Peggy McCracken explains in her book, The Romance of Adultery: Queenship and Sexual Transgression in Old French Literature, that medieval stories of royalty often possessed the motif of Queens' that had issues with infidelity and the royal knights. McCracken explains,

The Tristan romances were probably the first stories about a courtly queen's enduring love for a knight, and several scholars have suggested that the introduction of the queen's courtly adultery in the Lancelot tradition was originally a rewriting of the Tristan legend ... This long elaboration of the Tristan material features the link between love and chivalry and suggests the potential benefits of even adulterous love for the court society protected by the knight's chivalric prowess, which is inspired by love ${ }^{16}$.

Overall, McCracken explains that the Queen's adulterous behavior is a common motif in French literature during the medieval period. The position of the Queen's power remains stable because she is an important figure, whether as a fictional character or a factual individual in medieval history. The audience may justify the love affair of a Queen and a knight because it is deemed as true courtly love. The courtly love is the idealized love an individual should have as presented in literature; therefore, a troubadour should be justify and convince his audience of the characters actions. In addition, the authors' of different medieval text tend to describe the Queen as angelic, so most men would want to pursue her. For example, in Chrétien de Troyes story, Lancelot is nearly bewitched by Guinevere's presence and sheer beauty. Also, King Arthur does not show any interest in his wife. Chrétien de Troyes describes the characters of Lancelot and Guinevere as the most compatible characters in the romance. Their adulterous behaviors are justified because of their compatibility and natural love for one another. The audience does not feel sympathy for King Arthur because of his indifference towards his wife's wellbeing throughout the story. Overall, Chrétien de Troyes describes Guinevere as the most desirable woman in the text.

Marie de Champagne and her mother, Eleanor of Aquitaine played a significant role in justifying the extent to adultery. These two women were known for the "court of love" which one would listen to cases of adultery and decipher whether the adultery was lustful or based on true love. There are twenty-one documents supporting that the courts of love were real. It is believed that Eleanor of Aquitaine was the first to have a court of love and other aristocratic women, like her daughter, followed in her footsteps throughout all of France during the twelfth century ${ }^{17}$. There are questions of whether the courts of love actually existed, but some of the court of love's documents and "judgments were written down and remain to constitute undeniable documentation of the interest inspired by questions of love in the refines and cultivated aristocratic society of that era ${ }^{18}$." Although, there is not much documentation of the courts of love surviving, but there is enough information to acknowledge the presence of the courts. The troubadours shaped the way medieval society looked at love; but the aristocratic women in power also inspired and shaped the way love was viewed publically, accepted, and understood to the different social classes.

During the twelfth century, many wives and daughters were considered property rather than a member of the family. The woman was an object ready to be sold and bought for the benefit and interest of a family. Marriage was a sacrament, but was also an act for personal gain. Whether it was a gain of wealth, political status, and/or social status, a marriage always came with benefits. Overall, marriage was a contract of love that should not be broken by another individual. An extramarital relationship was considered stealing another man's property. One of the aristocratic women ruling their court of love would act like a judge in hope to defend true love or condemn the sinners of inappropriate lust, the treason against another man, and the stealing of another man's wife ${ }^{19}$. The court of love was a

Legitimation of adultery-whether actual (in certain precise conditions excluding normal coitus) or simply spiritual and moral-is one of the essential characteristics of fin'amor, that is, love considered as a means of achieving perfection, an operating method within the grasp of sincere overs who wish to reach a higher place of consciousness ${ }^{20}$.

However, many of the aristocratic women ruling their courts of love were flexible in the cases of lovers. Marie de Champagne believed marriage forced the couple to suffer together in an unhappy marriage, while lovers were complacent with one another. Lovers expressing true courtly love for one another were not punished as severely as lustful individuals lacking love and devotion ${ }^{21}$. However, not all cases in the court of love were cases of adultery and lovers. Some of the cases in the court of love just clarified public love; "To establish a general rule that would allow lovers to model their behavior on a consensus everyone found satisfactory ... lovers are not alone in this world ${ }^{22}$." Love and the public display of love was becoming more public and more accepted during the twelfth century. The act of courting a woman was becoming acceptable. The court of love helped make societal views and commentary understanding of men courting women. More people during the twelfth century were becoming comfortable in expressing their emotions for others publically and in social settings. There was a need for the social judgments to be defined.

Chrétien attempts to convince his audience of the acceptable adultery and rightfully defend the characters within the romance Lancelot or The Knight of the Cart. 
Within the story, Guinevere and Lancelot have an extramarital relationship, disregarding King Arthur very publically. The complicated story explains one aspect of their relationship,

Then the king led him to see the queen. This time the queen did not let her eyes lower toward the ground but went happily up to him and had him sit beside her, honoring him with her kindest attentions. Then they spoke at length of everything that came into their minds; they never lacked for subject matter, which Love supplied them in abundance. When asked Lancelot saw how well he was received, and that anything he said pleased the queen, he asked her in confidence: "My lady, I wonder why you acted as you did when you saw me the other day and would not say a single word to me. You nearly caused my death, yet at that moment I didn't have enough confidence to dare to ask you, as now I am asking you. My lady, if you would tell me what sin has caused me such distress, I am prepared to atone for it at

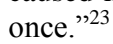

The relationship between Lancelot and Guinevere is described as true love as well as courtly love. They share communication between each other to explain their love and pains regarding their extramarital affair. As alluded to in the quote, Lancelot has not only shamed himself by riding in the dwarf's cart, but he has also shames Guinevere's image as Queen and his relationship with the Queen by riding in the cart. He did not think with reason when getting into the cart because he was so preoccupied with his love for Guinevere and worried of her well-being. Lancelot and Guinevere speak much more about their relationship with one another than Guinevere does with King Arthur. Although, the treasonous affair with the Queen is an act punishable by death, Guinevere and Lancelot justify their actions because they love each other so much. The medieval audience would be familiar with this justification of adultery in their medieval story and understand the actions of the Queen and her lover knight. Lancelot is willing to sacrifice anything and everything for Guinevere to love him in return. He had already sacrificed his honorable and respectable name by getting into the dwarf's cart; there is nothing that would stop him from loving Guinevere. Lancelot's whole being is to love her. He can no longer think with reason because of her influence on him. Lancelot and Guinevere portray a couple with all-encompassing love for one another. The twelfth century audience would be convinced of the love between the two aristocratic lovers. Chrétien de Troyes provides the plot and characters that help justify the adulterous relationship even though the lovers are disloyal to their King.

Overall, Queen Guinevere in Chrétien de Troyes Lancelot or the Knight of the Cart was a purely fictional character developed to represent the ideal woman. The troubadours in Southern France developed women that could be idealized during the twelfth century. Although women could not be perfect, like some of the troubadours' stories and poems, the women in the stories would be acceptable within their society. The troubadours' stories provided a transition, in a form of entertainment, to help accept courtly love in a larger context. However, the female troubadours provided arguments against courtly love. Through their poems and stories, they did communicate love relatable but rather frustrating and formidable. The men in the twelfth century wanted the ideal women but would not provide women with the ideal man. The women troubadours provide honest and authentic representations of women during the twelfth century. The courts of love, like the ones administered by Eleanor of Aquitaine and Marie de Champagne and various other aristocratic women, helped provide a transition of accepting love in the public context. Specifically, Chrétien de Troyes, as the most notable author of the French during the twelfth century, helped justify the actions of the fictional characters and their adulterous ways. The French public would know his story of Lancelot or The Knight of the Cart and find the story as a realistic plot and relatable into real life contexts. Guinevere and Lancelot are idealized lovers; they are not based on historical figures. Their unconditional love is the ideal relationship between two lovers. In addition, Chrétien de Troyes characters were not perfect but rather have character flaws and weaknesses. Their acts of adultery is considered treason against King Arthur but their actions are based on their true love and courtly love for one another. If this case of royal love affair was brought to the court of love, it is likely that the aristocratic women, like Marie de Champagne or Eleanor of Aquitaine, would find their love reasonable and their adulterous actions justifiable. The relationship is treason because they are being disloyal to their King, but their passion and adoration for one another is natural and unconditional. Overall, Chrétien de Troyes medieval romance, Lancelot or The Knight of the Cart, is a purely fictional representation of ideal love during a tumultuous period of social acceptance and transition of understanding love.

\section{Works Cited}

Bogin, Meg. The Women Troubadours: An Introduction to the Women Poets if the Twelfth Century Provence and a Collection of

Their Poems. London: Norton \& Company, 1980. Print.

"Chretien De Troyes." Chambers Biographical Dictionary (Bio Ref Bank) (1997): Biography Reference Bank (H.W. Wilson). Web.

"Chretien De Troyes." Encyclopedia Of The Middle Ages (2000): Biography Reference Bank (H.W. Wilson). Web. "Chretien De Troyes." European Authors, 1000-1900 (1967): Biography Reference Bank (H.W. Wilson). Web. "Courtly Love." Oxford English Dictionary. Web. 4 Dec. 2014.

"Eleanor of Aquitaine." The Oxforn Dictionary of National Biography. Web. 4 Dec. 2014.

Giles, Frances and Joseph. Women in the Middle Ages: The Lives of Real Women in a Vibrant age of Transition. New York, Harper Perennial, 1980. Print.

Kibler, W. William. "Chrétien de Troyes, Lancelot, or The Knight of the Cart." The Romance of Arthur: An Anthology of Medieval Texts in Translation. Ed. Norris J. Lacy and James J. Wilhelm. New York: Routledge, 2013. 112-180. Print.

Markale, Jean. Courtly Love: The Path of Sexual Initiation. Rochester: Inner Traditions, 2000. Print.

McCracken, Peggy. The Romance of Adultery: Queenship and Sexual Transgression in Old French Literature.

Philadelphia: University of Pennsylvania Press, 1998. Print. Paterson, Linda M. The World of the Troubadours: Medieval 
Occitan Society, c. 1100- c.1300. Cambridge: Cambridge University Press, 1995. Print.

Troubadour.” Oxford English Dictionary. Web. 4 Dec. 2014.

\section{Bibliography}

Block, Howeard R. Medieval Misogyny and the Invention of Western Romantic Love. Chicago: University of Chicago Press, 1991. Print.

Bogin, Meg. The Women Troubadours: An Introduction to the Women Poets of the Twelfth Century Provence and a Collection of Their Poems. London: Norton \& Company, 1980. Print.

Burns, Jane E. Courtly Love Undressed: Reading Through Clothes in Medieval French Culture. Philadelphia: University of Pennsylvania Press, 2002. Print.

Carey, Stephen M. "Chartrian Influence And German Reception: Dating The Works Of Chrétien De Troyes." Arthuriana 20.3 (2010): 21-44. MLA International Bibliography. Web.

"Chretien De Troyes." Chambers Biographical Dictionary (Bio Ref Bank) (1997): Biography Reference Bank (H.W. Wilson).

Web.

"Chretien De Troyes." Encyclopedia Of The Middle Ages (2000): Biography Reference Bank (H.W. Wilson). Web.

"Chretien De Troyes." European Authors, 1000-1900 (1967): Biography Reference Bank (H.W. Wilson). Web.

"Courtly Love." Oxford English Dictionary. Web. 4 Dec. 2014.

"Eleanor of Aquitaine." The Oxforn Dictionary of National Biography. Web. 4 Dec. 2014.

Gaggero, Massimiliano. "Verse And Prose In The Continuations Of Chrétien De Troyes' Conte Du Graal." Arthuriana 23.3 (2013): 3-25. MLA International Bibliography. Web.

Giles, Frances and Joseph. Women in the Middle Ages: The Lives of Real Women in a Vibrant age of Transition. New York, Harper Perennial, 1980. Print.

Gravdal, Kathryn. "Chrétien De Troyes, Gratian, And The Medieval Romance Of Sexual Violence." Signs 17.3 (1992): 558-585. MLA International Bibliography. Web.

Jeffrey, David Lyle. "Courtly Love And Christian Marriage: Chretien De Troyes, Chaucer, And Henry VIII." Christianity And Literature 59.3 (2010): 515-530. MLA International Bibliography. Web.

Kibler, W. William. "Chrétien de Troyes, Lancelot, or The Knight of the Cart." The Romance of Arthur: An Anthology of Medieval Texts in Translation. Ed. Norris J. Lacy and James J. Wilhelm. New York: Routledge, 2013. 112-180. Print.

Markale, Jean. Courtly Love: The Path of Sexual Initiation. Rochester: Inner Traditions, 2000. Print.

McCracken, Peggy. The Romance of Adultery: Queenship and Sexual Transgression in Old French Literature.

Philadelphia: University of Pennsylvania Press, 1998. Print.

Paterson, Linda M. The World of the Troubadours: Medieval Occitan Society, c. 1100- c.1300. Cambridge: Cambridge University Press, 1995. Print.

Pickens, Robert T. "Arthurian Time And Space: Chrétien's Conte Del Graal And Wace's Brut." Medium AEvum 75.2 (2006): 219- 246. MLA International Bibliography. Web.
Rezak, Brigitte Bedos. "Women, Seals, and Power in Medieval France, 1100-1350." Women \&Power in the Middle Ages. Ed. Mary Erler and Maryanne Kowaleski. Athens: University of Georgia Press, 1988. 61-82. Print. Schulenburg, Jane Tibbetts. "Female Sanctity: Public and Private Roles, ca. 500-100." Women \&Power in the Middle Ages. Ed. Mary Erler and Maryanne Kowaleski. Athens: University of Georgia Press, 1988. 102-125. Print. Troubadour." Oxford English Dictionary. Web. 4 Dec. 2014.

\section{Footnotes}

1 "Chretien De Troyes." European Authors, 1000-1900 (1967): Biography Reference Bank (H.W. Wilson). Web. 2 "Chretien De Troyes." Encyclopedia Of The Middle Ages (2000): Biography Reference Bank (H.W. Wilson). Web.

3 "Chretien De Troyes." Chambers Biographical Dictionary (Bio Ref Bank) (1997): Biography Reference Bank (H.W. Wilson). Web.

4 "Chretien De Troyes." European Authors, 1000-1900 (1967): Biography Reference Bank (H.W. Wilson). Web.

5 "Chretien De Troyes." Encyclopedia Of The Middle Ages (2000): Biography Reference Bank (H.W. Wilson). Web.

${ }^{6}$ Paterson, Linda M. The World of the Troubadours:

Medieval Occitan Society, c. 1100- c.1300. Cambridge:

Cambridge University Press, 1995. 259.

${ }^{7}$ Markale, Jean. Courtly Love: The Path of Sexual Initiation.

Rochester: Inner Traditions, 2000. 5.

${ }^{8}$ Paterson, Linda M. 72.

${ }^{9}$ Paterson, 74.

${ }^{10}$ Kibler, W. William. "Chrétien de Troyes, Lancelot, or The Knight of the Cart." The Romance of Arthur: An Anthology of Medieval Texts in Translation. Ed. Norris J. Lacy and James

J. Wilhelm. New York: Routledge, 2013.

${ }^{11}$ Bogin, Meg. The Women Troubadours: An Introduction to the Women Poets if the Twelfth Century Provence and a Collection of Their Poems. London: Norton \& Company, 1980. 13.

12 Paterson, 262.

${ }^{13}$ Giles, Frances and Joseph. Women in the Middle Ages: The Lives of Real Women in a Vibrant age of Transition. New

York, Harper Perennial, 1980. 45.

${ }^{14}$ Giles, 46.

${ }^{15}$ Giles, 46.

${ }^{16}$ McCracken, Peggy. The Romance of Adultery: Queenship and Sexual Transgression in Old French Literature.

Philadelphia: University of Pennsylvania Press, 1998. 17.

${ }^{17}$ Markale, 83.

${ }^{18}$ Markale 82.

${ }^{19}$ Markale, 35.

${ }^{20}$ Markale, 90 .

${ }^{21}$ Markale, 69 .

${ }^{22}$ Markale, 83

${ }^{23}$ Kibler, 155. 